\title{
Patients' Satisfaction and Loyalty Affect the Quality of Healthcare Services (A Clinical Study on Patients in Indonesia)
}

\author{
Sartika Harsa ${ }^{1}$, Ratna Indrawati ${ }^{2}$ \\ University of Esa Unggul ${ }^{1,2}$
}

\begin{abstract}
Related to the success of the healthcare services industries such as clinics, patients' satisfaction was one of the important keys to the success of a clinic. With satisfaction received by the patient, it was expected they will return for treatment at the same place. Patients' satisfaction, a modality to get more patients and their loyalties influence the profit received by the clinic. However, the satisfactions that will impact on loyalty have certainly inseparable from the quality of services provided. Clinical management was required to provide the best service to patients, which in reality the quality of service was still lacking in meeting the expectations of its patients. The purpose of this study will determine the effect of healthcare service quality on patient loyalty through patient satisfaction as moderating variable. Respondents used were 170. Data were analyzed using Structural Equation Model (SEM). The results of this study refer to the quality of healthcare services in the clinic affected patients' satisfaction, the service quality of the clinic influenced patients' loyalty, and patients' satisfaction influenced patients' loyalty.
\end{abstract}

Keywords: Service Quality, Satisfaction, Loyalty, Healthcare, Clinic, Patient

\section{INTRODUCTION}

Nowadays, the central part of Jakarta is a place that has significant and rapid development due to the large number of government and private offices, coupled with urbanites from outside the city migrating to Jakarta, increasing population. However, these developments were not equipped with good healthcare facilities such as hospitals and clinics as a means of improving public health. High service quality, is patient satisfaction. Kotler and Keller (2012) suggested that patient satisfaction whether if a patient feels of pleasure or disappointed will be arised after comparing between services that they expected and the services that they obtained or perceived. Satisfaction must be the main concerns for the clinic, because patient satisfaction is an absolute thing in these increasingly widespread competitions.

Furthermore, in enhancing the service quality standard, it is absolutely necessary to measure the patient satisfaction so it can be known how far the dimensions of service quality that have been carried out improved in order to meet patient expectations and surely make the patients become loyal to the clinic they visit. As in previous research, Chang, Chen and Lan (2013) analyzed patients at the Taiwan Health Center, the results obtained the perception of medical services had a positive impact on service quality and patient satisfaction. Service quality giving the positive way in influencing patient trust the patient's trust gave a positive influence on patient satisfaction.

Tang (2012) in his results, stated that patient satisfaction has positif impact towards the healthcare services, and patient trust affected the patient's life satisfaction. Atinga, Nkrimah and Domfeh (2012) in their research in Ghana National Center Hospital concluded that service quality and patient trust affected life satisfaction of the patient. Aiken, Sermeus, Heede, Sloane, Busse, McKee, Bruyneel, Rafferty, Griffifths, Casbas, Tishelman, Scott, Brzostek, Kinnunen, Schwendiman, Heinen, Zikos, Sjetne, Smith and Lee (2012), researching at European and United States hospitals. By the results, found the investors prefer to invest in hospital's technology facilities rather than investing in hospital staff, so that the service quality of the hospital decerases which was giving negative impact on satisfaction and loyalty of the patient.

Alrubaiee and Alkaa'ida (2011) conducted research on patient at Al-Basher Sahab Hospital in Jordan. As the results, the healthcare service quality affected the patient trust, the service quality affected the patient satisfaction, the patient satisfaction affected the patient trust. Moreover, some variables from social demographic characteristic influence the healthcare quality, patient satisfaction and trust. Wu (2011) in his research state that the healthcare service quality affected to patient satisfaction and loyalty, also the brand image of the hospital. Lee and Chen (2010) examined Chimei Hospital in Taiwan, explained that his research positively correlated to healthcare provider, health service quality positively correlated to customer orientation and the service values positively correlated to the service quality. Furthermore, Raposo, Alves and Duarte (2009), examined patients at the Health Center in Portugal. As the 


\section{International Advanced Research Journal in Science, Engineering and Technology}

Vol. 6, Issue 2, February 2019

results of his study, he stated that patient treatment, staff, and facilities have positive effect on patient satisfaction. Espegel, Joel, Fandos, and Flavin (2008) in their results also prove that satisfaction influences customer loyalty in the food industry. Oliviera, Arieta, Temporini and Jose (2006), examined patients at the Estadual de Campinas University Hospital As the results of his research, patient satisfaction affected health services. While Beerli, Asuncion, Josefa, Martin and Quintana (2004) prove that in the retail banking market, satisfaction commonly known affected the customer loyalty.

Artha Graha Peduli Clinic as one of the healthcare providers is required to always improve their service quality. In order to improve the service quality, first thing to know about is the services that have been given to the patients so far already fit to the patient or not based on the patient expectations. As it's known from patient visiting data, there was a significant increasing of patient visit in February about 206 people and a decrease in September total 176 people around $14 \%$. This can be influences by patient dissatisfaction, a decrease in patient satisfaction towards the clinic or a decrease in service quality.

In this study, we examined the effect of service quality on patient satisfaction and loyalty at the Artha Graha Peduli Clinic in Jakarta, which to determine the quality of services provided by the Artha Graha Perduli Clinic in Jakarta can be done by comparing it with established healthcare service standards. In addition, the point of views from the employees and public were needed to visit the clinic as patient. Their opinions and point of views were very important since they feel the satisfaction that makes them return again to the clinic to use the healthcare services.

From the description of the background above, the objective of study that wanted to be achieved from this research were: to determine the effect of the service quality on patient satisfaction, to determine the effect of service quality on patient loyalty, to determine the effect of patient satisfaction on patient loyalty.

\section{LITERATURE REVIEW}

\subsection{SERVICE QUALITY}

According to Parasuraman, Zeithmal and Berry (1988) service quality is a reflection of consumers' evaluative perceptions towards services that is received at a certain time. Kotler and Keller (2012) define service quality as a performance that someone can offer to others. This performance can be an action that are intangible also do not affect in ownership of any goods and to anyone. Furthermore, service quality is measured using by the theory of Parasuraman et al. (1988) that is known as service quality based on five dimensions of service quality including first, tangibility; is a dimension of service quality including physical facilities, equipments, employees and communication tools, as well as the condition of the surrounding environment is tangible evidence of services that is given by service providers. Second, reliability; is a dimension in service quality in the form of the ability to deliver the service that is promised right in time and in consistent manner. Third, responsiveness; is the service quality dimension about the ability of staff to help customers and provide the services responsively. Fourth, assurance; is the dimension of service quality that includes ability, politeness and trustworthiness that are owned by staff, certainly without doubt. Fifth, emphaty; including easily making good relationships in communication and understanding the needs of customers

\subsection{SATISFACTION}

Kotler and Keller (2012) stated that patient satisfaction is a feeling of pleasure or disappointed that appear after comparing between services that they expected and the services that they obtained or perceived. If the performance is below the patient's expectations, the patient will feel dissatisfied. Zeithaml and Bitner (2011) explained, consumer satisfaction is "customer's evaluation of product or service in terms of whether that product or service has their needs and expectations." Consumers who are satisfied with the product or service they purchased and used, will use the service or the product that is offered again. Satisfied consumers tend to say something good about the product they use to others and this is what the company expected (Crosby, Evans and Cowles, 1990). Customer satisfaction can be measured through satisfaction to have, satisfaction in doing appropriate actions, overall satisfaction towards products and services (Crosby, et al., 1990 and Kim and Cha, 2002).

\subsection{LOYALTY}

Kotler and Keller (2012) stated that customer loyalty is a situation that consistently spends all existing budgets to buy products of services from the same seller. Loyalty is generally shown the intentions and desires to recommend to others (Gaur, Xu, Quazi and Nandi, 2011). Parasuraman, Zeithaml and Berry (2009) argue that customer loyalty in the context of service marketing as a response that is tightly bound by pledges or promises to uphold commitments that underlie the continuity of relationships, and usually reflected in the continuous purchase of the same service provider based on pragmatic dedication and constraints. The loyalty can be measured using the theory of Lin and Ding (2006) which consists of three dimensions, namely: subcription/repeat patronage, switching behavior, and recommendation. 


\section{International Advanced Research Journal in Science, Engineering and Technology}

Vol. 6, Issue 2, February 2019

\section{HYPOTHESIS DEVELOPMENT}

Lee, et al. (2010) say that the quality and value of services will influence consumer satisfaction and approaches to consumer habits. In addition, there is a direct or indirect influence. There are two factors that affect service quality, namely expected service and perceived service. If the service that is received or felt as expected, the quality of service is perceived as the ideal quality. Conversely, if the service that is received lower than customer expectations, then the quality of service is perceived poorly. Thus, the quality of service depends on the ability of the service provider to meet the patient's expectations. This is similar to the research by Tang, et al. (2012); Atinga, et al. (2012); Chang, et al. (2013) and Alrubaie and Alkaa'ida (2006), who concluded that there was an effect of high service quality that would increase customer satisfaction. Based on the literature above the hypothesis that can be proposed:

H1: Good healthcare services quality will increase patient satisfaction.

Service quality is the main factor that influences customer loyalty because customers are satisfied with their personal values and experience a positive mood towards service will have high loyalty to the company. Customers are often disloyal due to the poor service or the service quality which is lower than expected by customers. The study was conducted by Raposo, et al. (2008) said that service quality certainly has a positive and significant effect on customer loyalty. Potluri, et al. (2008) argue, the best quality of health services contributes to patient memory and loyalty. Boshoff, et al. (2004) define proof of positive relationships between service quality and loyalty, namely the act of buying a product again or using a service again, the quality of health services received by patients will have an effect on loyalty. This is in line with Wu's (2011) research that there is a positive relationship between service quality and customer loyalty. Based on the theory above, the hypothesis that can be proposed, namely:

H2: Good healthcare services quality will increase patient loyalty.

Zeithaml and Bitner (2011) argue, consumer satisfaction is "customer's evaluation of product or service in terms of whether that product or service has met their needs and expectations." Consumers feel satisfied with the product / service purchased and used will return to use the service or products that is offered. The optimum service quality will certainly create satisfaction for these patients which surely have an impact on patient loyalty. Patient satisfaction and patient loyalty are related to each other. Wu (2011) proves that a relationship that is built between patient satisfaction and patient repeated visits, influence the patient satisfaction on their repeated visits also make patient will be very loyal to the hospital. Beerli, et al. (2004) and Espegel, et al. (2008) the results of their research also prove satisfaction influences customer loyalty. From the literature above, the hypothesis can be proposed, namely:

H3: High satisfaction of patient will increase patient loyalty.

\section{RESEARCH METHOD}

This study was conducted on patients who came to visit the Artha Graha Perduli Clinic, having a number of visits more than once. The variables studied were service quality, satisfaction and loyalty. The study was conducted in January 2018 with the survey method. This research is descriptive quantitative design. Data collection was done by spreading patients to visit the Artha Graha Perduli Clinic in Indonesia and having more than one visit. The method of data analysis in this study uses Structural Equation Modeling (SEM). Hair, Anderson, Tatham and Black (2013) must be at least 5 times the number of questionnaires. So, in this study the number of operational questionnaires used was thirty-three, the samples were taken in this study $170(34 \times 5)$ respondents.

In our study there were exogenous variables; namely service quality, endogenous variables; namely loyalty and moderating variables; namely satisfaction. Measurement of service quality variables using dimensions from Parasuraman, et al. (1988) which include: reliability, responsiveness, assurance, tangibles and empathy. Satisfaction in this study was measured using dimensions from Crosby, et al. (1990) and Kim and Cha (2002), to have satisfaction in taking appropriate actions and overall satisfaction with products and services. While loyalty in this study is measured by using dimensions from Lin and Ding (2006) which include: repeat patronage, switching behavior and word of mouth.

This study uses confirmatory factor analysis, by conducting a validity test by looking at the value of the Kaiser-Msyer-Olkin measure of sampling (KMO) and measures of sampling adequacy (MSA). In this test the value obtained must be greater than 0.5 , which means that the analysis of factors is appropriate or suitable for use, and can be done with further processed (Malhotra, 2007). The service quality scale consists of 22 questionnaires and all questionnaires are valid, the satisfaction scale consists of 3 questionnaires and all questionnaires are valid, the loyalty scale consists of 9 questionnaires and all questionnaires are valid. Test reliability with Cronbach Alpha values> 0.5 which means reliable, so it can be said that the service quality questionnaires, patient satisfaction and patient loyalty can be said to be trusted as a data collection tool in research. 


\section{International Advanced Research Journal in Science, Engineering and Technology}

Vol. 6, Issue 2, February 2019

\section{RESULTS AND DISCUSSION}

The instruments used in this study have been tested for validity and reliability thus resulting in Construct Reliability (CR) and Variance Extracted (VE). Value of Service Quality (KP) VE of 0.85, value of Service Quality (KP) CR of 0.96. Value of Satisfaction (K) VE is 0.76 , value of Satisfaction (K) CR is 0.90 and Loyalty (L) VE is 0.83 , Loyalty value (L) CR is 0.93. Goodness of fit is suitable, where Chi Square $=77.47$, Degree of freedom $=38$, RMSEA $=0.078, \mathrm{ECVI}=0.79, \mathrm{AIC}=132.86, \mathrm{CAIC}=248.66, \mathrm{Critical} \mathrm{N}=134.43, \mathrm{RMR}=0.023$ and $\mathrm{PGFI}=0.53$.

The results of testing the first hypothesis (H1), found the results of the analysis support the hypothesis H1, it means the good quality of healthcare services will increase patient satisfaction. From the results of this test showed the quality of health services affected patient satisfaction at the Artha Graha Perduli Clinic. This indicates the quality of service provided was able to influence the affection of patients since indirectly make patients feel that they are cared for, they feel important and meaningful, that maked a sense of security, comfort and satisfaction appeared. Conversely, if the medical and non-medical staff do not care about the patient, the satisfaction of the patient will decrease even disappear and this will also affect the income of the Arta Graha Peduli Clinic.

Emphaty is one dimension of service quality that is very influential on patient satisfaction. One of the empathy that is done by Artha Graha Clinic is that during practice hours doctors are very concerned about patients by providing maximum service through giving detailed answers during consultations with patients, doctors in conducting checks in a thorough, patient, professional manner and in accordance with medical ethics, prescription is based on the methods and diagnosis of the patient's disease. Therefore Artha Graha Peduli Clinic always takes care of all the needs of patients besides doctors, nurses and employees. Therefore consumers or patients who are the sample in this study answered "overall satisfied with the services provided by the Artha Graha Peduli family". So if care (emphaty) is given to be able to exceed the expectations of his patients can lead to high satisfaction in patients.

This indicates the quality of service provided is able to influence the affection of patients because it can indirectly make patients feel that they are cared for, cared for and meaningful so that comes a sense of security, comfort and satisfaction. Conversely, if the medical and non-medical staff do not care about the patient, the satisfaction of the patient will decrease and even disappear and this will also affect the income of the Arta Graha Peduli Clinic. Furthermore, the results of this study are in line with the researcher Tang, et al. (2012); Atinga, et al. (2012); Chang, et al. (2013) and Alrubaie and Alkaa'ida (2006) who concluded that there was an influence of high service quality that would increase customer satisfaction.

In the results of testing the second hypothesis (H2), it was found that the results of the analysis support the $\mathrm{H} 2$ hypothesis, which means the good quality of healthcare services will increase patient loyalty. This shows that the quality of health services affects patient loyalty at the Artha Graha Perduli Clinic. High satisfaction indicates that patients get results from a service quality greater than what they expected. Results that can exceed their expectations can lead to loyalty from a patient. The form of loyalty from a patient can be in the form of purchasing products / services on an ongoing basis. This condition can make patients not easily switch to other hospital's competitors or clinics due to a sense of satisfaction and a bond of dependence on the services provided. The existence of a bond of dependence and satisfaction with the quality of services in the Artha Graha Perduli Clinic can make patients share their good experiences with the people closest to them. This will bring benefits to the company, can indirectly attract other new consumers. Conversely, poor service quality can make patients feel dissatisfied and as for the result, patients will turn to other hospitals or clinics which means patients do not behave loyally.

Patient satisfaction is an important assessment of the privilege of service, where the quality of service must be able to make patients feel comfortable and satisfied. The level of patient satisfaction affects the quality of service that prioritizes meeting the needs of consumers. Satisfaction that arises is the key to generating patient loyalty by providing high patient value. In addition, the emergence of patient satisfaction is very dependent on the perception and expectations of the patient.

High satisfaction indicates that patients get results from a quality service greater than what they expected. Results that can exceed their expectations can lead to loyalty from a patient. The form of loyalty from a patient can be in the form of purchasing products / services on an ongoing basis. This condition can make patients not easily switch to other competing hospitals or clinics due to a sense of satisfaction and a bond of dependence on the services provided. The existence of a bond of dependence and satisfaction with the quality of services in the AGP Clinic can make patients share their good experiences with the people closest to them. This will bring benefits to the company, can indirectly attract other new consumers. Conversely, poor service quality can make patients feel dissatisfied and result in patients turning to other hospitals or clinics so that patients do not behave loyally. The results of this study are in line with previous studies conducted by Raposo, et al. (2009) and Wu (2011) stating that good service will increase patient loyalty. 


\section{International Advanced Research Journal in Science, Engineering and Technology}

Vol. 6, Issue 2, February 2019

In the results of testing the third hypothesis (H3), it was found that the results of the analysis supported the hypothesis H3, namely high patient satisfaction will increase patient loyalty. This means that patient satisfaction affects patient loyalty at the Artha Graha Perduli Clinic. As the results for appropriate services or can be said according to what the patient needs, of course, can make patients feel satisfied in undergoing treatment at the Artha Graha Perduli Clinic means they can make patients loyal. Besides, the fast respond of the clinic staff in working can minimize or even cause no complaints from patients. This can make patients not hesitate to reuse Artha Graha Perduli Clinic services for treatment or can be said to be the attitude of loyalty shown by patients.

Medical staff's quick response in working with the right results can create a professional impression on medical staff at the AGP Clinic. The results of service that is right or can be said according to what the patient needs, can certainly make patients feel comfortable and safe in undergoing treatment at the AGP Clinic so that they can make patients loyal. In addition, the speed of the clinician in working can minimize or even cause the absence of patient's exhaustion. This can make patients not hesitate to reuse AGP Clinic services for treatment or can be said to be the attitude of loyalty shown by patients. The good experience of patients undergoing treatment at the AGP Clinic, is expected to make patients share their good experiences with the people closest to them. This attitude can also be said as one of loyal attitudes.

Customer loyalty can be said to be a support in the marketing strategy used by the AGP Clinic to advance and develop which will eventually add to the company's incame. Meanwhile the AGP Clinic also takes steps to improve employee loyalty so that it can provide good health services to patients so that patients feel satisfaction after being treated by the Artha Graha Peduli Clinic, that is, include them in the process and provide training in support and compensation information so that they want to do that. The results of this study further corroborate the results of previous Beerli et al. (2004), Espegel, et al. (2008), Raposo, et al. (2009), Wu (2011); Aiken, et al. (2012) which states that there is an influence between customer satisfaction on customer loyalty.

\section{Mediation Analysis of Satisfaction}

Mediation variable analysis can be done through two approaches, namely: difference in coefficient and multiplication. The first approach is done by conducting an examination through analysis with and without mediating variables, while the second method is done using the Sobel procedure (Hair, et al., 2013). Through the coefficient multiplication method, the results of the research hypotheses indicate the influence of mediating variables on patient satisfaction between health service quality variables on patient loyalty, in which patient satisfaction mediation ariabel is used to connect between service quality and patient loyalty.

Based on the Path The t-value diagram results from testing the coefficient difference on the research model) shows that service quality has a direct effect on patient satisfaction with a value of $t=12.65(>1.96)$, service quality has a direct effect on loyalty with a value $t=3.89(>1.96)$ and satisfaction has an effect on patient loyalty with a value of $t=7.48$ (>1.96). So that it can be concluded that patient satisfaction can mediate the relationship of service quality to patient loyalty. Service quality has a direct effect on patient loyalty and service quality has an indirect effect on patient loyalty through mediating patient satisfaction. This is usually called partial mediation analysis because it can affect directly and indirectly. It can be said that the better the quality of services provided at the Artha Graha Peduli Clinic, the higher the patient's satisfaction. Service companies such as Klinik Artha Graha Peduli that satisfy their customers make customers feel happy, thus making customers remain loyal and not easily switching to buying products or services to other competitors.

\section{CONCLUSIONS AND RECOMMENDATIONS}

\section{Conclusion}

The results that can be concluded from this study: (1) there is an influence of the quality of healthcare services on patients' satisfaction at the Artha Graha Perduli Clinic, also said that the quality of a good service will increase patient satisfaction; (2) there is the influence of the quality of healthcare services on patient loyalty at the Artha Graha Perduli Clinic, which means the quality of good health services will increase patient loyalty; (3) there is an influence of patient satisfaction on patient loyalty at the Artha Graha Perduli Clinic, it can be said that high satisfaction of the patient will increase the patient's loyalty; (4) there is an influence of the quality of healthcare services on patient loyalty mediated by patient satisfaction at Artha Graha Perduli Clinic.

\section{Research Limitations}

The limitations in this study can be taken into consideration for further research. These limitations include: (1) in this study a sample of research only 170 respondents; (2) the prospective respondent does not want to be used as a sample that it takes a long time to wait for the next prospective respondent: (3) the subject of this study is limited to the patients of the Artha Graha Perduli Clinic without involving other visitors who receive clinical services. Subject characteristics 


\title{
International Advanced Research Journal in Science, Engineering and Technology
}

\author{
Vol. 6, Issue 2, February 2019
}

taken ie patients coming to visit to the Artha Graha Perduli Clinic, have more than one visit; (4) this research only discusses the quality of service, satisfaction and loyalty of patients, (5) there is a possibility that the respondents do not fill in the truth or only fill based on the ideal conditions expected and not the actual conditions that were happened.

\section{Suggestion}

The development of future research can be added by other variables that were able to influence patient loyalty, for example: adequate infrastructure facilities, organizational culture variables that were used as characteristics of the organization such as greeting culture, and motivation variables given by the leadership of the organization. Subsequent research can be carried out on the object of research in other companies or industries and other organizations in order to obtain more objective results certainly with wider coverage.

\section{REFERRENCES}

[1]. Aiken, L.H., Sermeus, K., Heede, K.V., Sloane, D.M., Busse, R., McKee, M., Bruyneel, L., Rafferty, A.M., Griffifths, P., Casbas, M.T.M., Tishelman, C., Scott, A., Brzostek, T., Kinnunen, J., Schwendiman, R., Heinen, M., Zikos, D. Sjetne, I.S., Smith, H.L., and Lee, A.K. 2012. Patientsafety, Satisfaction, and Quality of Hospital care: Cross Ssectional Surveys of Nurses and Patients in 12 Countriesin Europe and the United States. British Medical Journal. Vol $344 ; 1717$.

[2]. Alrubaiee, L., and Alkai'daa, F. 2011, The Mediating Effect of Patient Satisfaction in the Patients' Perceptions of Healthcare Quality-Patient Trust Relationship. International Journal of Marketing Studies. Vol. 3, No.1.

[3]. Atinga, R.A., Nkrimah, G.A., and Domfeh, K.A. 2012. Managing Healthcare Quality in Ghana: a Necessity of Patient Satisfaction. International Journal of Health Care Quality Assurance. Vol. 24 No. 7.

[4]. Boshoff, C. and Gray, B. 2004. The Relationships Between Service Quality, Customer Satisfaction and Buying Intentions in the Private Hospital Industry. Journal Business Management, Vol. 35 (4).

[5]. Beerli, Asuncion, Josefa D, Martı'n and Agustı'n Quintana. 2004. A model of Customer Loyalty in the Retail Banking Market. European Journal of Marketing 38 (1/2): 253-275.

[6]. Chang, S.C., Chen, Y.S., and Lan, T.Y. 2013, Service Quality, Trust, and Pasien Satisfaction in Interpersonal-Based Medical service encounters. Taiwan: Biomed Central Research Vol.13;22

[7]. Crosby, L. A., Evans, K. R. and Cowles, D. 1990, Relationship quality in services selling: an interpersonal perspective. Journal of Marketing. Vol. 54. pp.68-81.

[8]. Espegel., Joel., Fandos, C., and Flavian, C. 2008. Consumer satisfaction: A key factor of consumer loyalty and buying intention of a PDO food product. British Food Journal (110), (9): 865-881.

[9]. Gaur, S.S., Xu, Y., Quazi, A., and Nandi, S. 2011. "Relational Impact of Service Providers' Interaction Behavior In Healthcare". Managing Service Quality, Vol. 21 No. 1, pp. 67-87.

[10]. Hair, J.F., Anderson, R.E., Tatham, R.L., and Black, W.C. 2013. Multivariate Data Analysis, Fifth Edition. USA: Prentice Hall International.

[11]. Kim, W.G., and Cha, Y. 2002. Antecendents and Consequences of Relationship Quality in Hotel Industry. Hospitally Management. Vol. 21. No.3. pp 321-338.

[12]. Kotler, P., and Keller, K.L. 2012. Marketing Management 13. New Jersey: Pearson Prentice Hall, Inc.

[13]. Lee, W.I., Chen, C.W., Chen, T.H., and Chen, C.Y. 2010. The Relationship Between Consumer Orientation, Service Value, Medical Care Service Quality and Patient Satisfaction: The Case of a Medical Center in Southern Taiwan. African Journal of Business Management. Vol. 4(4), pp. 448-45.

[14]. Lin, C. P., and Ding, C. G. 2006. Evaluating the Group Differences in Gender During the Formation of Relationship Quality and Loyalty in ISP Service. Journal of Organizational and End User Computing. Vol. 18, 38-62

[15]. Maholtra, N. 2007. Marketing Research: an applied orientation. Pearson education, inc., fifth edition. New Jearsey: USA.

[16]. Oliviera, D.F.D., Arieta, C.E.L., Temporini, E.R., and Jose, N.K. 2006. Quality of Health Care: Patient Satisfaction in a University Hospital. Trabalho Realizado na Disciplina de Oftalmologia da Faculdade de Ciências Médicas da Universidade Estadual de Campinas. 69(5): 731-6.

[17]. Parasuraman, A., Zeithaml, V.A and Berry, L.L. 2009. Devering Quality Service. New York: The Free Press.

[18]. Multiple item for Measuring Customer Perception of Service Quality. Journal of Retailing. Vol.64. p.12-40.

[19]. Potluri, R.M. 2008. Assement of Effectiveness of Marketing Communication Mix Element in Ethiopian Service Sector. African Journal of Business Management. Volume 2 (3).

[20]. Raposo, M.L. Alves, H.M., and Duarte, P.A. 2008. Dimensions of Service Quality and Satisfaction in Health Care: a Patient's Satisfaction Index. Business and Economics Department. 200-209.

[21]. Tang, L. 2012. The Influence of Patient's Satisfaction with Medical Service Delivery, Assessment of Medical Service, and Trust in Health Delivery System on Patient's Life Satisfaction in China. Biomed Central Research. Vol.10 : 111.

[22]. Wu, C.C. 2011. The Impact of Hospital Brand Image on Service Quality, Patient Satisfaction and Loyalty. African Journal of Business Management. Vol.5.

[23]. Zeithaml, V.A., and Bitner. M.J. 2011. Service Marketing Strategy. New York: John Wiley and Sons. 